\title{
Estimation of Impact of Sea Level Rise on Land and Water Resources When Data Is Sparse - Case of Colombo
}

\author{
Gregory Shahane De Costa ${ }^{1, *}$, Wajira Dassanayake ${ }^{2}$ \\ ${ }^{1}$ Department of Civil Engineering, Unitec Institute of Technology, New Zealand \\ ${ }^{2}$ Department of Accounting and Finance, Unitec Institute of Technology, New Zealand
}

Copyright $\bigcirc 2016$ by authors, all rights reserved. Authors agree that this article remains permanently open access under the terms of the Creative Commons Attribution License 4.0 international License.

\begin{abstract}
This paper highlights investigation and the impacts on the changes in groundwater table caused by sea level rise due to climate change in Wellington New Zealand and translates it to possible impacts in Colombo Sri Lanka. Similarly the possible loss of land due to elevated sea level rise has been investigated. In the past 100 years sea level raised on average by $0.2 \mathrm{~m}$ in Wellington region and it is predicted that by the 2090 sea level will increase by $0.8 \mathrm{~m}$ and by 2115 almost $1 \mathrm{~m}$. Therefore an investigation has been carried out by developing a three-dimensional hydrodynamic numerical model. Numerical model was developed using comprehensive groundwater modelling package FEFLOW 6.1. Once the model was developed and calibrated, four scenarios were investigated. Scenario 1 assumed the increase of $0.5 \mathrm{~m}$ of the mean seawater level (MSL). Scenario 2, Scenario 3 and Scenario 4 assumed an increase of $1.0 \mathrm{~m}, 1.5 \mathrm{~m}$ and $2.0 \mathrm{~m}$ MSL respectively. The changes were compared in nine observation bores and the results are presented. Thereafter taking into consideration the variability of rainfall these estimations have been translated for Colombo. The loss of land is also analysed for those four cases. The loss of the land due to sea level rise was estimated by using ArcGIS (ESRI, 2012). The affected area by the sea level is defined by the corresponding contour, $0.5 \mathrm{~m}, 1.0 \mathrm{~m}, 1.5 \mathrm{~m}$ and $2.0 \mathrm{~m}$, and the coastline which corresponds to $0 \mathrm{~m}$ contour and the sea level at present day. Again these results have been translated to Colombo and presented.
\end{abstract}

Keywords Sea Level Rise, Loss of Land, Changes to Water Table

\section{Introduction}

Bell and Hannah [1] study revealed that in the past 100 years sea level raised on average $0.2 \mathrm{~m}$ in Wellington region and they have also predicted that by the 2090 sea level will increase by $0.8 \mathrm{~m}$ and by 2115 almost $1 \mathrm{~m}$. This change will have impact on groundwater table. It will also encroach on land resulting in loss of land. The purpose of this study is to present investigation on changes in groundwater table due to sea level rise as well as loss of land due to sea level rise.

\section{Sea Level Rise Scenario}

In the last 100 years the sea level rise had an average yearly rate of $2.03 \pm 0.15 \mathrm{~mm}$, with a prediction of $1 \mathrm{~m}$ by 2115. Sea level rise projections for the next 100 years are based on the outputs of global emissions models using a range of emissions scenarios. Figure below shows four possible scenarios of sea level rise and historical mean sea level recorded at Wellington.

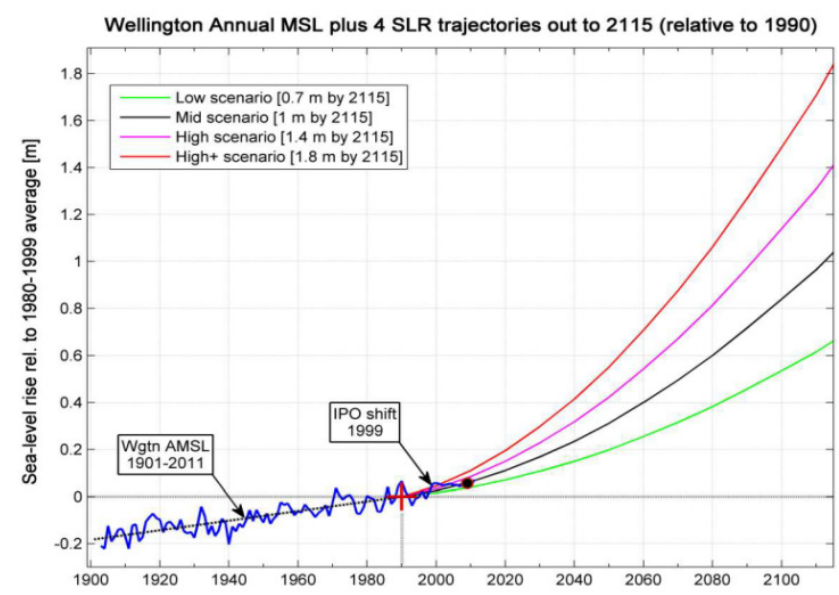

\subsection{Storm Effects}

Storm surge is the temporary increase in sea level above that expected by tidal variation caused by extreme meteorological conditions such as low pressure system and/or strong winds.

Wave setup is the super-elevation in water level across the surf zone caused by energy expended by breaking waves. This occurs even in calm conditions, but is exacerbated during storm events.

The following figure illustrates how these components interact. 


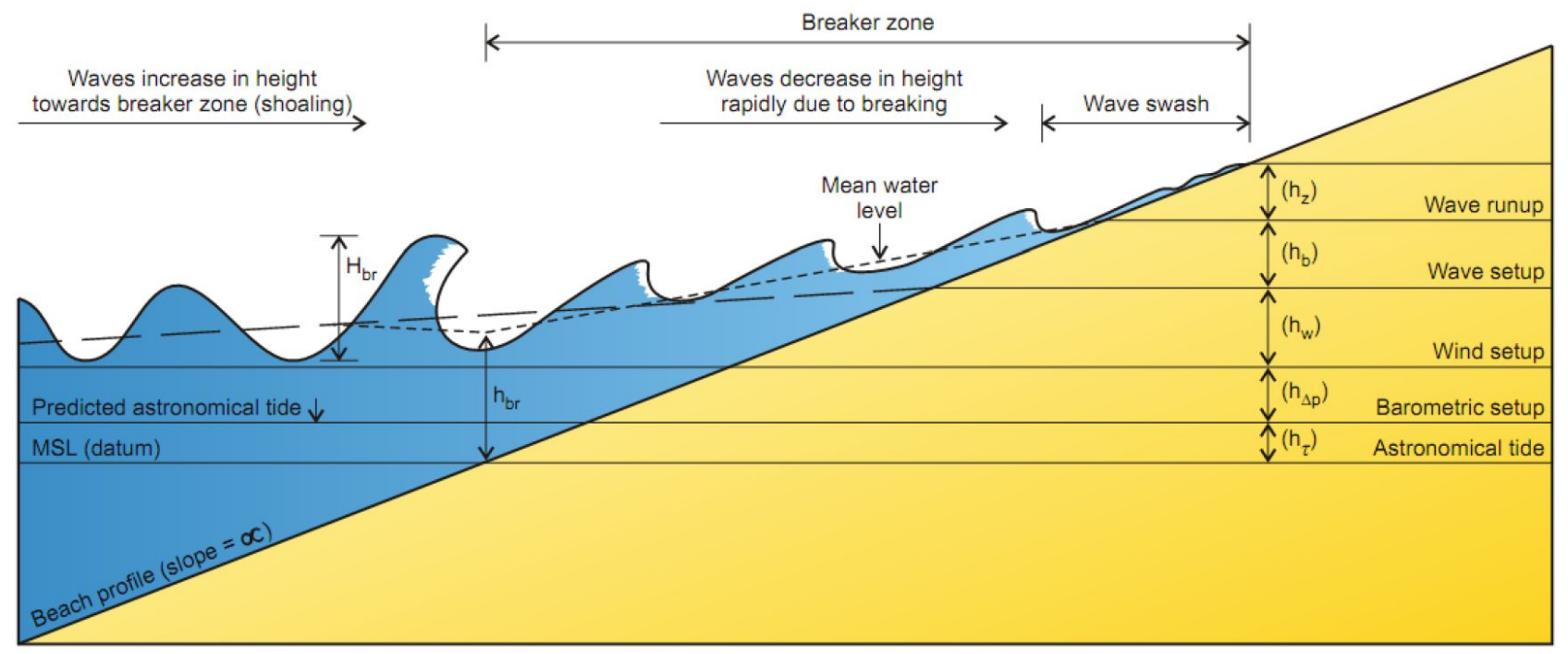

Storm components (Source: Shand et al 2011)

Table 1. Sea level rise scenario components

\begin{tabular}{|c|c|c|c|c|c|c|}
\hline Scenario & $\begin{array}{c}\text { Sea level rise } \\
(\mathrm{m})\end{array}$ & $\begin{array}{c}\text { MHWS } \\
(\mathrm{m} \mathrm{RL})\end{array}$ & $\begin{array}{c}\text { Sea level variability } \\
(\mathrm{m})\end{array}$ & $\begin{array}{c}\text { Storm } \\
\text { effects }(\mathrm{m})\end{array}$ & $\begin{array}{c}\text { Total no storm effects } \\
(\mathrm{m} \text { RL) }\end{array}$ & $\begin{array}{c}\text { Total with storm } \\
\text { effects (m RL) }\end{array}$ \\
\hline 1 & 1.0 & 0.83 & 0.25 & 1.1 & 2.1 & 3.2 \\
\hline 2 & 0.5 & 0.83 & 0.25 & 1.1 & 1.6 & 2.7 \\
\hline 3 & 1.5 & 0.83 & 0.25 & 1.1 & 2.6 & 3.7 \\
\hline 4 & 2.0 & 0.83 & 0.25 & 1.1 & 3.1 & 4.2 \\
\hline
\end{tabular}

As it could be seen that the effect of sea level rise could be varied from $2.7 \mathrm{~m}$ to $3.2 \mathrm{~m}$ (even after discounting the $2.0 \mathrm{~m}$ sea level rise scenario 4), the authors have suggested that studies should cover three different cases of sea level rise regardless of the time period: $0.5 \mathrm{~m}, 1.0 \mathrm{~m}$, and $1.5 \mathrm{~m}$. Therefore the changes to the water table and loss of land will be analysed for the $1^{\text {st }}$ three cases.

\section{Inundation Modelling in Wellington (Tutulic et al. [6])}

Inundation typically refers to an area permanently submerged, but is also sometimes used in relation to temporary inundation during storm events. Inundation modelling was undertaken using GIS. A "bathtub" concept was applied, where a uniform depth of water is applied to the existing land surface. This model is widely used in studies of this type. The limitations to this approach particularly are that it does not consider any dynamic or changing coastal processes, which could change areas of inundation and its duration. However, it is suitable to provide high level extents of inundation hazard and is commonly applied as a first order assessment (AGDCC, 2009).

\subsection{Results}

The inundation due to the 3 scenarios of sea level rise is shown in the table below. The table below (Table 2) shows the area affected by the Inundation. These areas were calculated using GIS modelling and then calculating area effected by flooding.

Table 2. The area affected by the Inundation

\begin{tabular}{|c|c|c|}
\hline Scenario & $\begin{array}{c}\text { Area - no storm } \\
\text { effects (ha) }\end{array}$ & $\begin{array}{c}\text { Area - with storm } \\
\text { effects (ha) }\end{array}$ \\
\hline 1-SLR $1.0 \mathrm{~m}$ & 418 & 903 \\
\hline 2-SLR $0.5 \mathrm{~m}$ & 141 & 737 \\
\hline 3 - SLR $1.5 \mathrm{~m}$ & 695 & 1016 \\
\hline
\end{tabular}

\subsection{Loss of the Land Due to Sea Level Rise}

Estimated land loss of the land varies from $0.84 \mathrm{~km} 2$ for $0.5 \mathrm{~m}$ increase up to $1.70 \mathrm{~km} 2$ for the increase of $2.0 \mathrm{~m}$. The area of inland part of the zone is $26.2 \mathrm{~km}^{2}$, therefore the loss of the land expressed in percentage is varying from $3.23 \%$ to $6.51 \%$. The results are presented below in Table 3 .

Table 3. Loss of the land due to sea level rise

\begin{tabular}{|c|c|c|}
\hline $\begin{array}{c}\text { Sea level } \\
\text { increase } \mathbf{( m )}\end{array}$ & $\begin{array}{c}\text { Loss of the } \\
\left.\text { land } \mathbf{( k m}^{\mathbf{2}}\right)\end{array}$ & $\begin{array}{c}\text { Percent of inland of the LHGZ } \\
\text { lost due to sea level rise (\%) }\end{array}$ \\
\hline 0.5 & 0.84 & 3.23 \\
\hline 1.0 & 1.17 & 4.49 \\
\hline 1.5 & 1.45 & 5.54 \\
\hline 2.0 & 1.70 & 6.51 \\
\hline
\end{tabular}




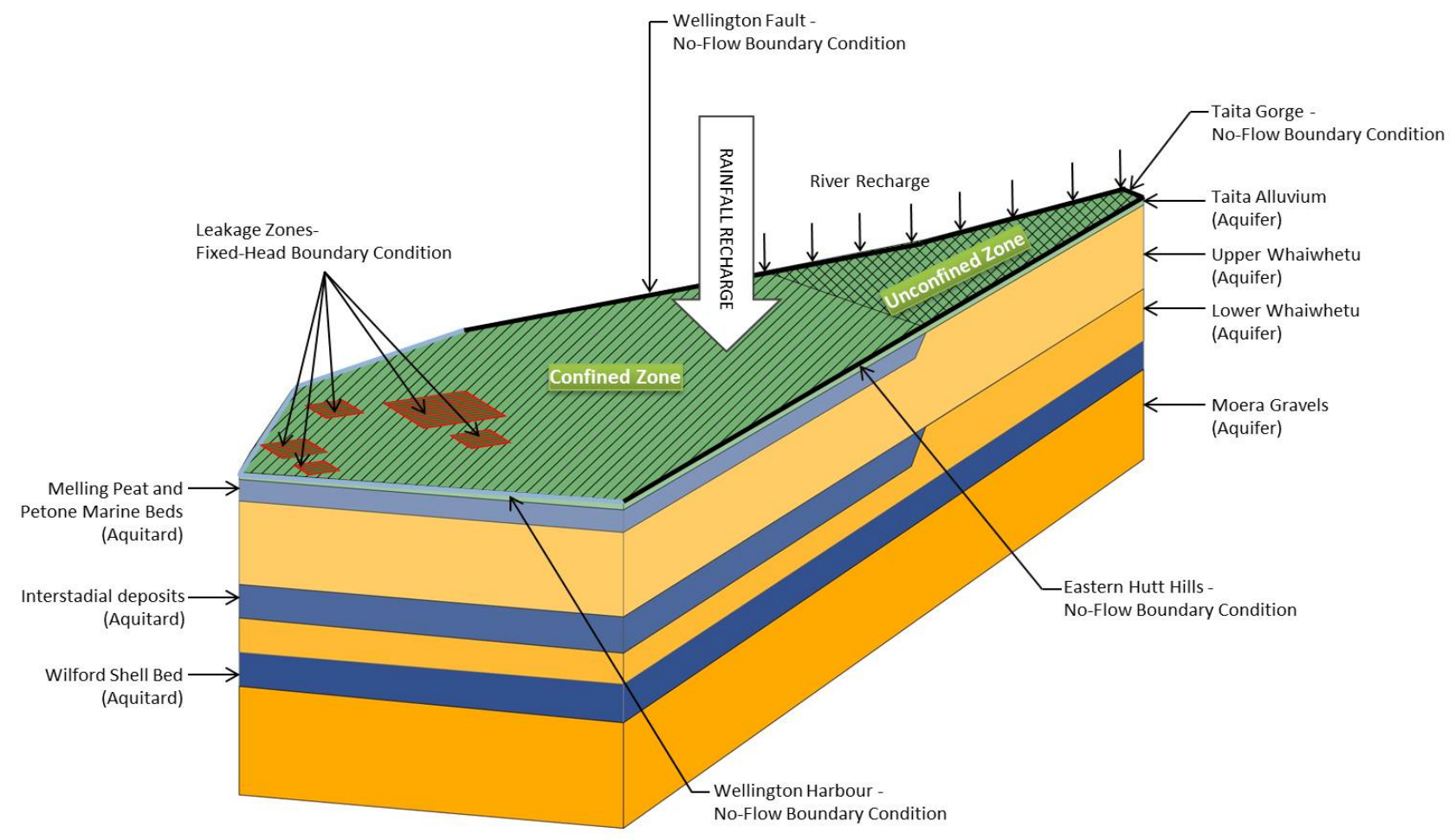

Conceptual Model

\section{Ground Water Modelling in Wellington (Tutulic et al. [6])}

The conceptual model, based on the model described in Phreatos [5], consists of seven geological layers. The northern boundary is at Taita Gorge where gravels thin out. Western boundary of the model domain coincides with Wellington fault. Eastern model boundary is defined by Eastern Hutt Hills. Southern boundary lies within the Wellington Harbour, between Somes Island and entrance to Wellington Harbour. The upper boundary of the conceptual model is defined by the elevations of the land surface. This was obtained from the University of Otago - $15 \mathrm{~m}$ digital elevation model. The lower boundary was set as bottom Moera Gravel Layer. The thicknesses of the layers were determined from the bore logs given in the Revision of the numerical model for the Lower Hutt groundwater zone explained in Phreatos [5]. The inflow in the model is the recharge from the rainfall in the onshore zone of the model domain and from the river in the unconfined zone. According to Harding [4] Discharge is assumed to be into the Wellington harbour via submarine springs on the sea floor.

\section{Modelling Software - FEFLOW 6.1}

The modelling software FEFLOW 6.1 (DHI-WASY, [2, 3]) was chosen for building the model. FEFLOW 6.1 is the existing version of software that was first developed in Germany in 1979. It is at a high level of development and refinement and has wide global use by universities, consultants, and government and private research organizations. FEFLOW 6.1 is a three-dimensional finite-element software package for modelling subsurface water flow and contaminant transport. It can be used to build two- or three-dimensional models with steady-state or transient conditions, and includes graphical user interfaces for model building, model input, and post-processing of model output (DHI-WASY, [2, 3]).

\section{Finite-Element Mesh Generation and 3D Discretization}

To define the elevations of the slices, the node positions ( $x$ and y coordinates) were exported from FEFLOW as an ESRI point shapefile, and imported into ArcGIS. The Slice 1 elevations (ground surface level, above mean sea level) at the nodes were obtained using bilinear interpolation between the elevations at the centres of the cells of the $15 \mathrm{~m}$ digital elevation model (Otago, 2011). To estimate elevations for all other slices, a first-order polynomial (planar), linear-regression trend of depth values for each stratigraphic unit from the bore logs of 29 bores were used in Phreatos [5] within the LHGZ. Values of this trend surface were determined at the node positions using bilinear interpolation, and the values were subtracted from the previously estimated Slice 1 elevations to give elevations for the all of the remaining slices. Values of all node elevations for each slice were combined into an eight ESRI shapefiles (one shapefile correspond to one slice) containing the node number, $\mathrm{x}$ and $\mathrm{y}$ coordinates, node elevation, and slice number. These files were imported into FEFLOW, and the node elevations were assigned using the FEFLOW data assignment tool. Once the layers have been 
defined the layer type needed to be defined. The "Free surface" option in FEFLOW was chosen for modelling the characteristics of the Layer 1 (Tatita Alluvium) for the model runs. For Layer 2 (Melling Peat and Petone Marine
Bed) the option dependent was chosen, which means that the layer above defines current layer. This means that the Layer 2 property will depend on Layer 1 . All the rest layers were set up as confined at all times.

\section{Boundary Conditions}

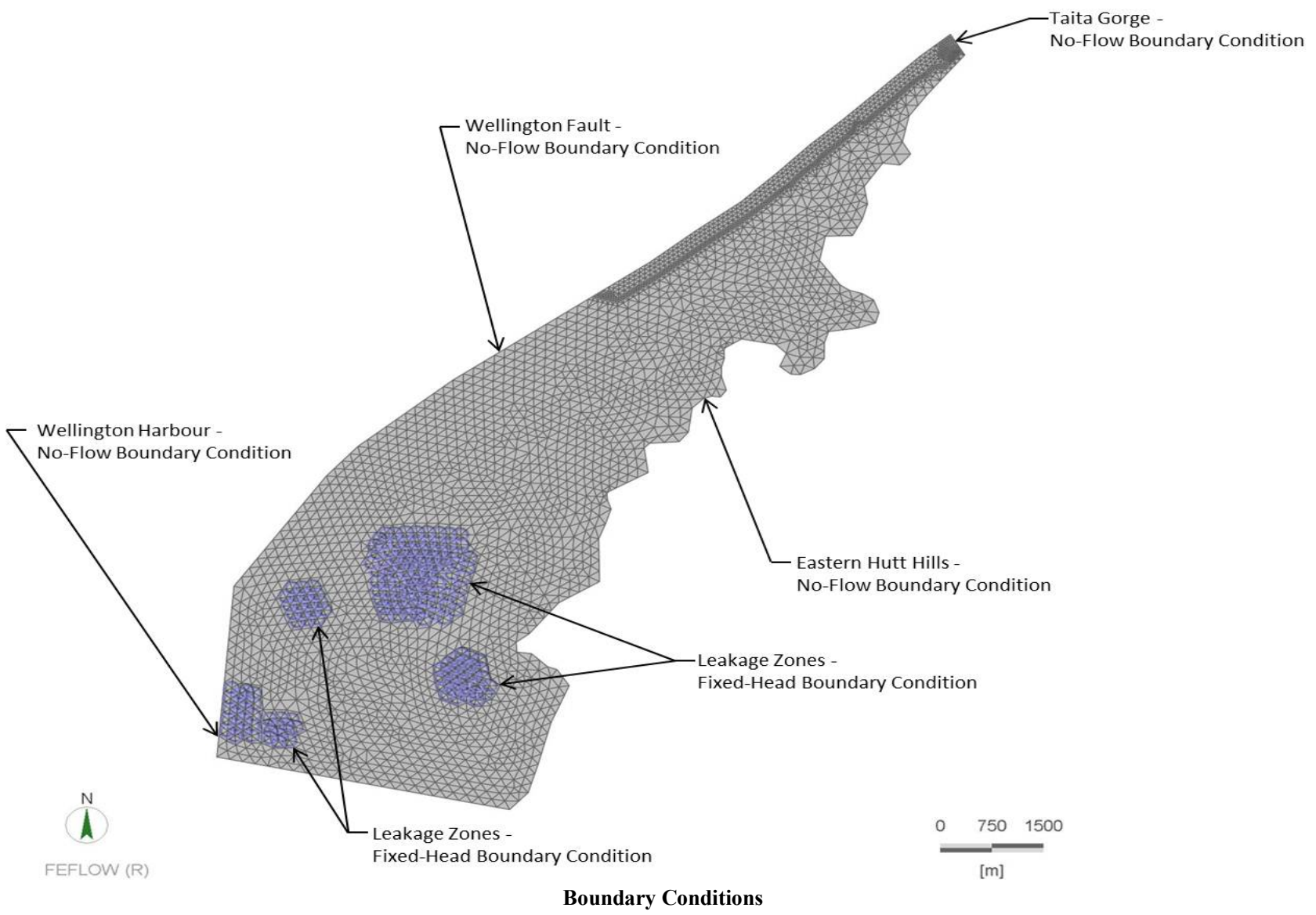

Eastern, southern, western and northern boundary: assumed to be no flow boundaries

Leakage zones: fixed head, set at a value of $0.0 \mathrm{~m}$ above sea level.

\section{Model Calibration}

Due to insufficient data regarding river flows in the Hutt River and lack of series of rainfall data, calibration was done only for steady state conditions. Calibration was based on comparison of simulated and observed water levels in nine observation bores. Bores were selected according to data availability. Many runs were performed in order to match the simulated levels with observed ones and for each model run the Nash-Sutcliffe efficiency coefficient (Nash and Sutcliffe 1970) was also calculated. The model was accepted as suitable for further use when there was the same number of overestimated and underestimated water levels in observation bores and when the Nash-Sutcliffe coefficient was a maximum and close to 1 . 
Comparison of simulated and observed groundwater levels
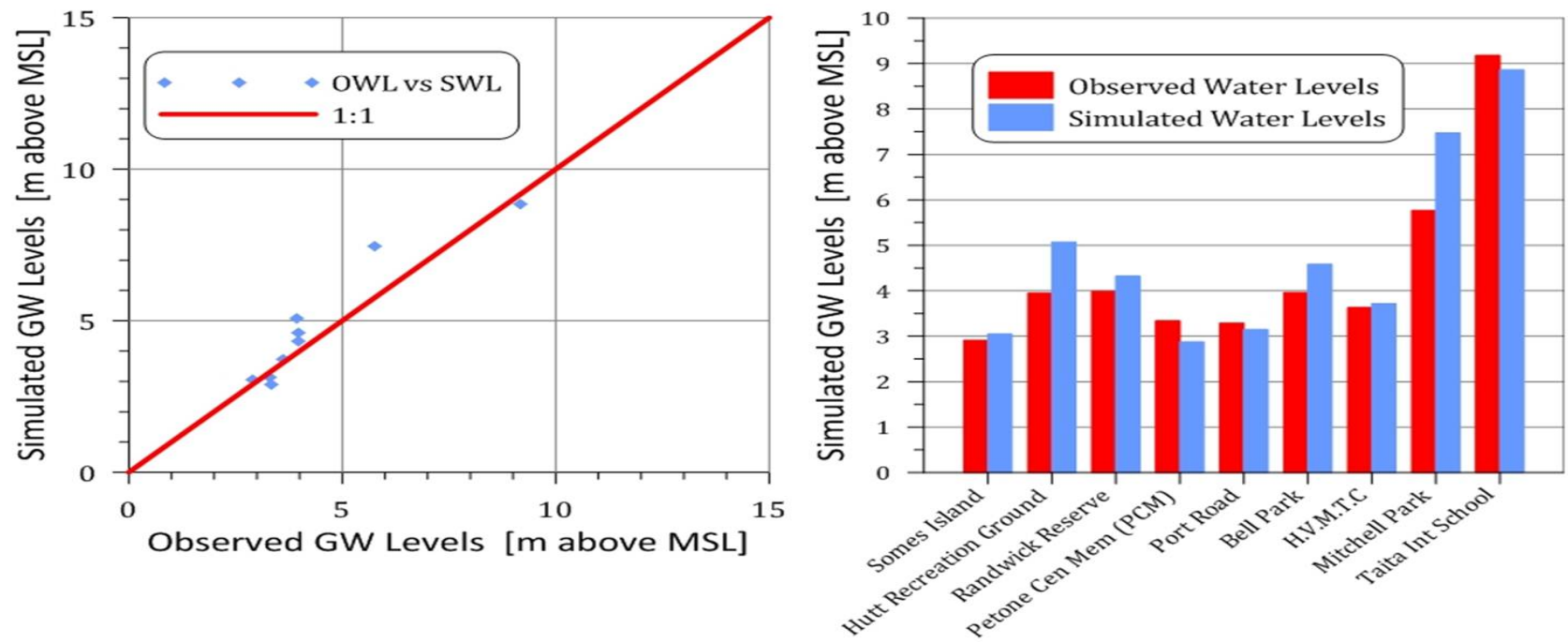

Table 4. Investigation results

\begin{tabular}{|c|c|c|c|c|}
\hline \multirow{5}{*}{ Site Name } & \multicolumn{4}{|c|}{ Scenario } \\
\hline & 1 & 2 & 3 & 4 \\
\hline & \multicolumn{4}{|c|}{ Increase (m) } \\
\hline & 0.5 & 1.0 & 1.5 & 2.0 \\
\hline & \multicolumn{4}{|c|}{ Change in water table $(\mathrm{m})$} \\
\hline Somes Island & 0.17 & 0.61 & 0.98 & 1.39 \\
\hline Hutt Recreation Ground & 0.05 & 0.48 & 0.85 & 1.23 \\
\hline Randwick Reserve & 0.11 & 0.54 & 0.91 & 1.31 \\
\hline Petone Centennial Museum (PCM) & 0.13 & 0.56 & 0.94 & 1.34 \\
\hline Port Road & 0.06 & 0.48 & 0.85 & 1.24 \\
\hline Bell Park & 0.07 & 0.49 & 0.86 & 1.25 \\
\hline Hutt Valley Memorial Technical College (H.V.M.T.C) & 0.04 & 0.47 & 0.833 & 1.22 \\
\hline Mitchell Park & 0.00 & 0.42 & 0.78 & 1.17 \\
\hline Taita Intermediate & 0.00 & 0.39 & 0.76 & 1.15 \\
\hline
\end{tabular}

\section{Investigation of changes to groundwater table due to sea level rise}

Four scenarios were used for investigation of the changes of the water table due to sea level rise. Scenario 1 assumes increase of $0.5 \mathrm{~m}$ of the mean seawater level (MSL), Scenario 2, $1.0 \mathrm{~m}$, Scenarios 3, $1.5 \mathrm{~m}$ and Scenario 4, $2.0 \mathrm{~m}$.

This increase of the mean sea level in the model was represented by changing fixed head boundary condition at the leakage zones for each scenario. Therefore there were four model runs for each scenario. The results of $1 \mathrm{~m}$ increase scenario show that increase in the ground water level will vary from $0.39 \mathrm{~m}$ to $0.61 \mathrm{~m}$. The rise in elevation decreases from the south towards the northern part of the aquifer.

\section{Translating to Colombo, Sri Lanka}

Sri Lanka is an island off the southeast coast of Indian
Ocean directly affected by the sea level rise. The deforestation, global warming, overpopulation, depletion of freshwater aquifers, beach erosion aggravate the submergence issues, thus, a special attention must be focused on the policy making in coastal management. Our endeavour in this pilot study is to approximately predict the likely loss of land as a result of the sea level rise in the coastal area of Colombo. The major limitation of this estimation process is the sourcing of precise data for Colombo. We understand that the major drawback in our study is the unavailability of the accurate data for an accurate comparison. And so for many locations round the world. One of the primary objectives of this study is to make an awareness on sea level rise and possible issues in the case study area as well as the potential to identify such issues in location where data is sparse or not available.

Due to the data limitation, the natural environmental conditions excluding rainfall variation are similar and could be applied synonymously. Based on rainfall variation 
assuming other environmental factors are being held constant, the results show $95 \%$ confidence. Thus, we adopt a simplistic statistical approach to estimate the confidence intervals of the loss of land $\left(\mathrm{km}^{2}\right)$ based on New Zealand results obtained by Tutulic et al. [6, 7].

Confidence intervals consist of a range of values that act as appropriate estimates of the unknown population parameter/s, however, in seldom, none of these values may represent the value of the parameter/s. The level of confidence of the confidence interval would indicate the probability that the confidence range captures this true population parameter given a distribution of samples. We adopt the following equation in our estimation process.

$$
\bar{X} \pm Z \sigma / \sqrt{n}
$$

In this statistical estimation we assumed that all the variables except the rainfall variation used in the estimation of Wellington remain the same. We understand that this approach is an over simplification, but data limitations force us to adopt this strategy to highlight the potential impact of sea level rise on the coastal areas in Colombo. Thus, our estimation must be examined cautiously as there may have been unrecognized variations in temperature, humidity, soil permeability, natural and human causes of coastal erosion in Colombo compared to Wellington.

The figure below provides a comparison of rainfall variation in Colombo and Wellington.

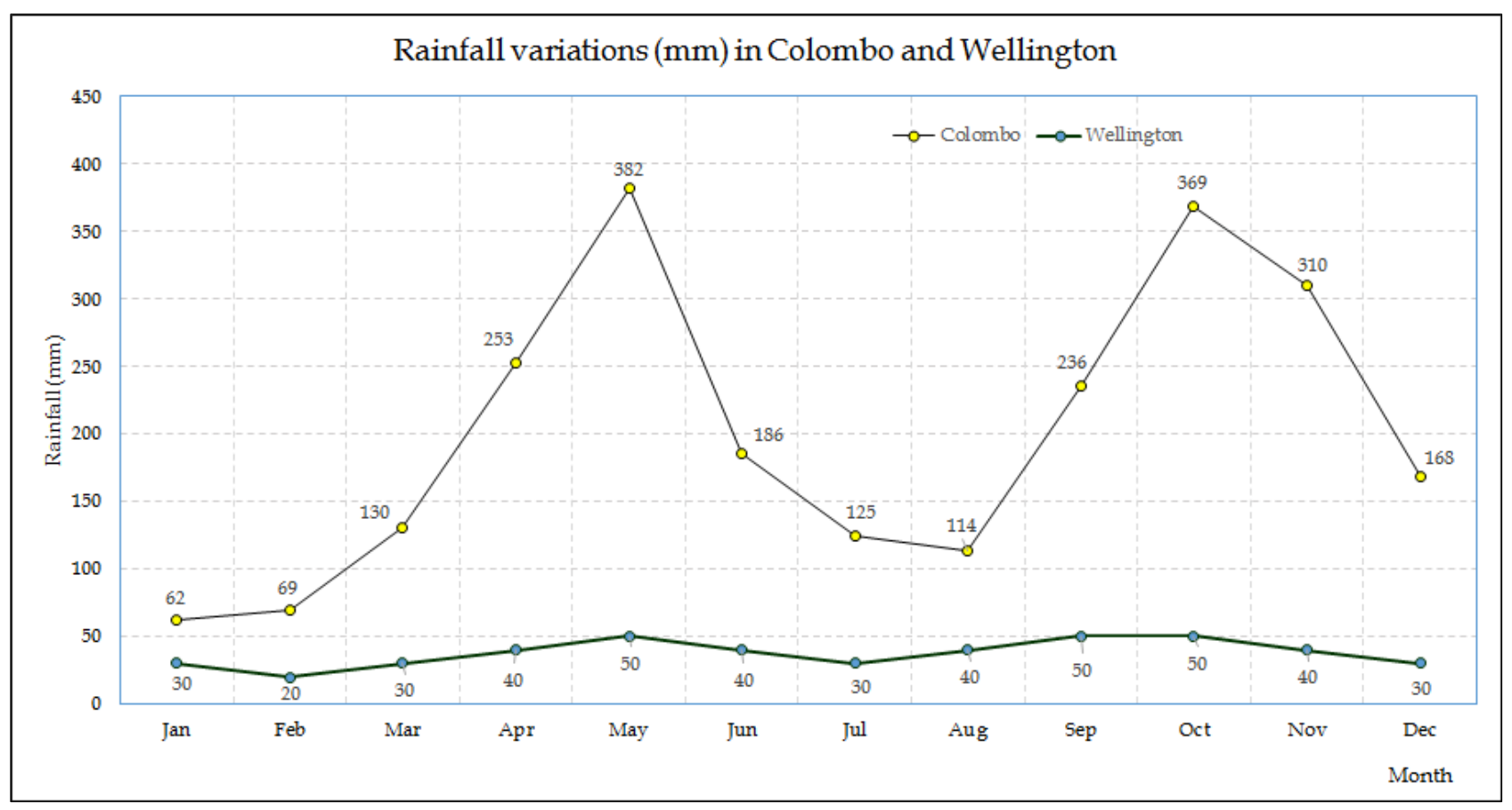

Comparison of rainfall variations $(\mathrm{mm})$ in Colombo and Wellington

Table 5. Confidence limits for the land area affected by sea level rise the Colombo Groundwater Zone (CGZ)

\begin{tabular}{|c|c|c|c|c|}
\hline \multirow{2}{*}{ Sea level increase (m) } & \multicolumn{2}{|c|}{ Loss of the land $\left(\mathbf{k m}^{2}\right)$ [at 95\% confidence] } & $\begin{array}{c}\text { Percent of inland of the CGZ lost due to sea level rise } \\
\text { (\%) [at 95\% confidence] }\end{array}$ \\
\cline { 2 - 5 } & Lower Limit & Upper limit & Lower Limit & Upper limit \\
\hline 0.5 & 0.78 & 0.90 & 3.17 & 3.29 \\
\hline 1 & 1.11 & 1.23 & 4.43 & 4.55 \\
\hline 1.5 & 1.39 & 1.51 & 5.48 & 5.60 \\
\hline 2 & 1.64 & 1.76 & 6.45 & 6.57 \\
\hline
\end{tabular}

Similarly the change in groundwater table has been estimated to be as follows.

The tables 5 provides the 95 percent confidence limits for the land area affected by sea level rise in the Colombo Groundwater Zone (CGZ) at $0.5 \mathrm{~m}$ sea level rise, $1 \mathrm{~m}$ sea level rise, $1.5 \mathrm{~m}$ sea level rise and $2 \mathrm{~m}$ sea level rise.

Similarly the change in groundwater table has been estimated to be as in Table 6. 
Table 6. Confidence limits for the change in groundwater table

\begin{tabular}{|c|c|c|c|c|c|c|c|c|}
\hline \multirow{6}{*}{ Site Name } & \multicolumn{8}{|c|}{ Scenario } \\
\hline & \multicolumn{2}{|c|}{1} & \multicolumn{2}{|c|}{2} & \multicolumn{2}{|c|}{3} & \multicolumn{2}{|c|}{4} \\
\hline & \multicolumn{8}{|c|}{ Increase (m) } \\
\hline & \multicolumn{2}{|c|}{0.5} & \multicolumn{2}{|c|}{1} & \multicolumn{2}{|c|}{1.5} & \multicolumn{2}{|c|}{2} \\
\hline & \multicolumn{8}{|c|}{ Change in water table (m) [at $95 \%$ confidence] } \\
\hline & $\begin{array}{c}\text { Lower } \\
\text { Limit }\end{array}$ & $\begin{array}{c}\text { Upper } \\
\text { limit }\end{array}$ & $\begin{array}{c}\text { Lower } \\
\text { Limit }\end{array}$ & $\begin{array}{c}\text { Upper } \\
\text { limit }\end{array}$ & $\begin{array}{c}\text { Lower } \\
\text { Limit }\end{array}$ & $\begin{array}{c}\text { Upper } \\
\text { limit }\end{array}$ & $\begin{array}{c}\text { Lower } \\
\text { Limit }\end{array}$ & $\begin{array}{c}\text { Upper } \\
\text { limit }\end{array}$ \\
\hline Elevation level 1 & 0.11 & 0.23 & 0.55 & 0.67 & 0.92 & 1.04 & 1.33 & 1.45 \\
\hline Elevation level 2 & -0.01 & 0.11 & 0.42 & 0.54 & 0.79 & 0.91 & 1.17 & 1.29 \\
\hline Elevation level 3 & 0.05 & 0.17 & 0.48 & 0.60 & 0.85 & 0.97 & 1.25 & 1.37 \\
\hline Elevation level 4 & 0.07 & 0.19 & 0.50 & 0.62 & 0.88 & 1.00 & 1.28 & 1.40 \\
\hline Elevation level 5 & 0.00 & 0.12 & 0.42 & 0.54 & 0.79 & 0.91 & 1.18 & 1.30 \\
\hline Elevation level 6 & 0.01 & 0.13 & 0.43 & 0.55 & 0.80 & 0.92 & 1.19 & 1.31 \\
\hline Elevation level 7 & -0.02 & 0.10 & 0.41 & 0.53 & 0.77 & 0.89 & 1.16 & 1.28 \\
\hline Elevation level 8 & -0.06 & 0.06 & 0.36 & 0.48 & 0.72 & 0.84 & 1.11 & 1.23 \\
\hline Elevation level 9 & -0.06 & 0.06 & 0.33 & 0.45 & 0.70 & 0.82 & 1.09 & 1.21 \\
\hline
\end{tabular}

Elevation 1 to 9 refers to distances in $500 \mathrm{~m}$ interval starting from the coast.

\section{Summary}

Sea level rise scenarios have been analysed and modelled using GIS for Wellington. These values have then been translated to estimate the loss of land in Colombo for sea level rise scenarios. It has been found that the percentage loss of land could be varying from 3 to $6.5 \%$ for the Colombo coastal zone. The GIS modelling is a simplistic approach to identifying possible risk areas and effects of infrastructure. Nevertheless, the extents can be used to priorities areas for further inundation assessments.

Similarly a numerical model was developed and calibrated by using FEFLOW. The model was accepted as calibrated once the number of overestimated and underestimated levels in observation bores were similar and when the Nash-Sutcliffe coefficient was a maximum. Calibrated model was then used for investigation of the changes to groundwater table. Again four scenarios were investigated for the increase of $0.5 \mathrm{~m}, 1.0 \mathrm{~m}, 1.5 \mathrm{~m}$ and 2.0 $\mathrm{m}$. The average increase in groundwater levels in Wellington was found to be $0.07 \mathrm{~m}, 0.49 \mathrm{~m}, 0.86 \mathrm{~m}$ and $1.25 \mathrm{~m}$ respectively while in Colombo it is estimated to be varying from 0 to $1.45 \mathrm{~m}$.

\section{Acknowledgements}

The authors wish to acknowledge the Asia Pacific Network (APN) for funding provided to conduct the research, and all the related institutes for facilitating the research.

\section{REFERENCES}

[1] Bell, R. G. \& Hannah, J. 2012. Sea-level variability and trends: Wellington Region- Prepared for Greater Wellington Regional Council. Hamilton (NZ). NIWA.

[2] DHI-WASY 2012a. FEFLOW 6.1. Berlin (DE): DHI-WASY $\mathrm{GmbH}$.

[3] DHI-WASY 2012b. FEFLOW 6.1 User Manual. Berlin (DE): DHI-WASY GmbH.

[4] Harding, S. J. 2000. The characteristics of the Waiwhetu Artesian Aquifer beneath Wellington Harbour including the spatial distribution and causes of submarine discharge. Unpublished MSc thesis, Victoria University of Wellington. Otago, U. O. 2011. 16s Wellington 15m DEM (NZSoSDEM v1.0). University of Otago.

[5] Phreatos 2003. Revision of the numerical model for the Lower Hutt groundwater zone. Prepared for Wellington Regional Council. Wellington (NZ).

[6] Tutulic, M., Shamseldin, A, Liefting. R., and De Costa G.S, Loss of land surface resulting from sea level rise, Proceedings of the 35 th Congress of the IAHR, in publication.

[7] Tutulic, M., Shamseldin, A. and De Costa G.S., Changes to Water resources resulting from sea level rise, Proceedings of the 35 th Congress of the IAHR, in publication 